\title{
Dual-targeting nanoparticles for reprogrammed $T$ cell responses in the tumor microenvironment
}

\author{
Alyssa K Kosmides ${ }^{1 *}$, Jonathan Schneck ${ }^{2}$ \\ From Society for Immunotherapy of Cancer 29th Annual Meeting \\ National Harbor, MD, USA. 6-9 November 2014
}

One of the largest obstacles in cancer immunotherapy involves overcoming the immunosuppressive tumor microenvironment [1]. While many therapies are focused primarily on activating antigen-specific CD8+ T cells, the tumor microenvironment often expresses immunosuppressive cytokines and other immunoregulatory proteins such as checkpoint blockade molecules that diminish their effects [2]. Programmed death ligand 1 (PD-L1) is an inhibitory checkpoint molecule upregulated on many cancers, including melanoma, ovarian cancer, and renal cancer [3]. This can shield a tumor from immune attack by binding to its receptor, PD-1, on T cells. We have developed a nanoparticle platform that combines blockade of PD-L1 with the $\mathrm{T}$ cell co-stimulatory signal, anti-4-1BB. This dual targeting system redirects effector cells to recognize target cells while simultaneously blocking checkpoint inhibitors. Antagonistic anti-PD-L1 antibodies and agonistic anti-4-1BB antibodies are conjugated to the surface of biocompatible 50-100 nm iron dextran nanoparticles. The nanoparticles cause a 6 -fold increase in IFN- $\gamma$ production by CD8+ T cells with an exhausted phenotype in the presence of tumor cells in vitro. Additionally, we have shown tumor suppression and a 30\% decrease of PD-1 expression in tumor infiltrating lymphocytes in an in vivo B16 mouse melanoma model. This approach may not only reprogram local signaling within the tumor microenvironment, but also promote polyclonal cytotoxic $\mathrm{T}$ cell responses in the absence of defining the antigenic specificity of the infiltrating $\mathrm{T}$ cells.

\section{Authors' details}

${ }^{1}$ Johns Hopkins University, Baltimore, MD, USA. ${ }^{2}$ Johns Hopkins School of Medicine, Department of Pathology, Institute for Cell Engineering, Baltimore, $M D$, USA.

\footnotetext{
'Johns Hopkins University, Baltimore, MD, USA

Full list of author information is available at the end of the article
Published: 6 November 2014

\section{References}

1. Rabinovich GA, Gabrilovich D, Sotomayor EM: Immunosuppressive strategies that are mediated by tumor cells. Annu Rev Immunol 2007, 25:267-96.

2. Freeman GJ, Sharpe AH, Kuchroo VK: Protect the killer: CTLs need defenses against the tumor. Nat Med 2002, 8:787-9.

3. Kamphorst AO, Ahmed R: Manipulating the PD-1 pathway to improve immunity. Curr Opin Immunol 2013, 1-8.

doi:10.1186/2051-1426-2-S3-P108

Cite this article as: Kosmides and Schneck: Dual-targeting nanoparticles for reprogrammed $\mathrm{T}$ cell responses in the tumor microenvironment. Journal for ImmunoTherapy of Cancer 2014 2(Suppl 3):P108.

Submit your next manuscript to BioMed Central and take full advantage of:

- Convenient online submission

- Thorough peer review

- No space constraints or color figure charges

- Immediate publication on acceptance

- Inclusion in PubMed, CAS, Scopus and Google Scholar

- Research which is freely available for redistribution 